\title{
Peri-Implant Crevicular Fluid Analysis, Enzymes and Biomarkers: a Systemetic Review
}

\author{
Erhan Dursun', Tolga Fikret Tözüm² \\ ${ }^{1}$ Department of Periodontology, Faculty of Dentistry, Hacettepe University, Ankara, Turkey. \\ ${ }^{2}$ Department of Periodontics, College of Dentistry, University of Illinois at Chicago, Chicago, Illinois, USA.
}

\author{
Corresponding Author: \\ Tolga Fikret Tözüm \\ Department of Periodontics, College of Dentistry \\ University of Illinois at Chicago \\ 801 S Paulina Street, Room 469G, Chicago, IL 60612 \\ USA \\ Phone: +1-312-996-0265 \\ E-mail: ttozum@uic.edu
}

\begin{abstract}
Objectives: To review the current understanding of the biomarkers and enzymes associated with different forms peri-implant diseases and how their level changes influence the pathogenesis of the inflammatory diseases around dental implants.

Material and Methods: An electronic search in two different databases was performed including MEDLINE (PubMed) and EMBASE between 1996 to 2016. Human studies analyse peri-implant crevicular fluid (PICF) biomarker and enzyme levels of implants having peri-implant mucositis and peri-implantitis published in English language, were evaluated. A systematic review was performed to assess which biomarkers and enzymes in PICF were used to identify the inflammatory conditions around dental implants.

Results: Fifty-one articles were identified of which 41 were further evaluated and included in the analysis. Due to significant heterogeneity between included studies, a meta-analysis could not be performed. Instead, a systematic descriptive review was performed.

Conclusions: Biomarkers and enzymes in peri-implant crevicular fluid have shown promising results in differentiating from peri-implant disease condition to health. However, due to inconsistent results and acquiring much evidence from crosssectional studies, additional evidence supported by randomized-controlled trials is needed to validate the links reported.
\end{abstract}

Keywords: biomarkers; dental implants; diagnosis; enzymes; inflammation.

\author{
Accepted for publication: 19 August 2016 \\ To cite this article: \\ Dursun E, Tözüm TF. \\ Peri-Implant Crevicular Fluid Analysis, Enzymes and Biomarkers: a Systemetic Review \\ J Oral Maxillofac Res 2016;7(3):e9 \\ URL: http://www.ejomr.org/JOMR/archives/2016/3/e9/v7n3e9.pdf \\ doi: $10.5037 /$ jomr.2016.7309
}




\section{INTRODUCTION}

Dental implant treatment is a successful, widespread and predictable treatment for tooth loss over the past 20 years however, an increasing number of implant failures caused by peri-implant diseases still take part in every day clinical dental practice [1]. Two forms of peri-implant inflammation have been identified in the literature: peri-implant mucositis and peri-implantitis. The American Academy of Periodontology (AAP) [1] stated that from a clinical standpoint, signs that determine the presence of peri-implant mucositis include bleeding on probing (BOP) and/or suppuration, which are usually associated with probing depths (PDs) $\geq 4 \mathrm{~mm}$ and no evidence of radiographic loss of bone beyond bone remodelling. Peri-implantitis is a progressive, irreversible disease of the bone and soft tissues around osseointegrated dental implants under masticatory function that is accompanied by bone resorption, reduced osseointegration, deep pocket formation and suppuration [2]. Despite divergences in the definition of peri-implantitis and the differential diagnosis of peri-implant diseases, studies have estimated that peri-implantitis affects approximately $10 \%$ of implants and $20 \%$ of patients [3] . According to a recent systematic review peri-implant mucositis and peri-implantitis have a prevalence ranging from 19 to $65 \%$ and from 1 to $47 \%$, respectively. On the other hand, another systematic review reported mean prevalence for peri-implant mucositis and peri-implantitis as $43 \%$ and $22 \%$, respectively [4].

The combination of clinical and radiographic parameters, such as PD, BOP, suppuration, mobility and marginal bone loss, are the commonly used parameters for the diagnosis of peri-implantitis [5]. However, these diagnostic processes might not be sensitive or specific enough to distinguish disease onset, development, and activity. Clinical measurements around implants as like natural teeth might be challenged by the force and direction of probing, implant geometry, prosthesis design and peri-implant soft tissue biotype. In addition, both peri-implant mucositis and periimplantitis lesions can present with BOP and/or suppuration, with PDs greater than $4 \mathrm{~mm}$. Therefore, clinicians and researchers may often observe the early, and sometimes the late diagnosis of peri-implantitis.

Early detection of peri-implant destruction, as well as monitoring progression of bone loss is extremely important. Currently, blunt surrogate markers are being used such as radiographs and peri-implant probing. These tests have obvious limitations as only history of disease may be detected. As main markers of peri-implantitis are bone destruction and inflammation, biomarkers and enzymes in implant sulcus fluid (PISF) focusing on these disease entities are of interest. Active components and mechanisms involved in the destructive process may thus be important perspectives within this field. Such knowledge may potentially lead to new diagnostic strategies and candidate disease markers for periimplant conditions.

A biomarker is an indicator of a biological state and can help to distinguish between normal and pathologic processes [6]. Presently, radiographs and clinical parameters such as, PD, clinical attachment level and BOP generally used for peri-implant condition diagnosis. Research to look at associations between certain biomarkers with health and/or disease can give more tools to clinicians for better understanding the pathogenesis of such peri-implant diseases []ㅡ. One of the main advantages of evaluating biomarkers is the repeatability and non-invasive nature of obtaining samples for analysis. Biomarkers can be measured in secretions such as saliva and gingival crevicular fluid, or in the case of implants, peri-implant crevicular fluid (PICF). An early pilot study demonstarted that this method of sampling provides reliable outcomes [7]. Since then, studies have been conducted to look at a vast array of biomarkers and enzymes around dental implants as an early sign of periimplantitis.

Today; there is large variation for the threshold of diagnosis for peri-implantitis, which may explain the wide range of percentages reported for its prevalence. Researchers and clinicians are always looking for adjunctive measures to aid in proper disease diagnosis, and the measurement of levels of enzymes and biomarkers is possible tool, and has gathered a lot of interest. Therefore, the purpose of this article was to review the current understanding of the biomarkers and enzymes associated with peri-implant diseases and how their level changes took part in the pathogenesis of the disease.

\section{MATERIAL AND METHODS Protocol and registration}

The methods of the analysis and inclusion criteria were specified in advance and documented in a protocol. The review was registered in PROSPERO, an international prospective register of systematic reviews. The protocol can be accessed at: 
http://www.crd.york.ac.uk/PROSPERO/display record.asp? ID=CRD42016035456.

The reporting of this systematic analysis adhered to the Preferred Reporting Items for Systematic Review and Meta-Analyses (PRISMA) Statement [ $\underline{8}$.

\section{Focus questions}

Which biomarkers and enzymes in PICF are used for distinguish between healthy implants and implants having peri-implant diseases? Do patients with periimplant diseases (peri-implant mucositis or periimplantitis) present higher levels of biomarkers and enzymes in PICF?

\section{Types of publications}

The review included studies on humans published in the English language. Letters, editorials, case reports, literature reviews, animal research, $\mathrm{PhD}$ theses, and abstracts were excluded.

\section{Information sources}

The search strategy incorporated the examination of electronic databases, supplemented by hand searches. A search was conducted on the National Library of Medicine database (MEDLINE) through its online site (PubMed) and EMBASE databases. Additionally, a hand search was conducted in the following journals: "Implant Dentistry", "Clinical Oral Implants Research"; "Clinical Implant Dentistry and Related Research", "European Journal of Oral Implantology", "International Journal of Oral \& Maxillofacial Implants", "Journal of Oral Implantology", "International Journal of Oral and Maxillofacial Surgery", "International Journal of Oral and Maxillofacial Surgery", "Journal of Periodontology", "Journal of Clinical Periodontology", "International Journal of Periodontics and Restorative Dentistry", "Journal of Prosthetic Dentistry", "International Journal of Endodontics, Journal of Endodontics", "Oral Surgery, Oral Medicine, Oral Pathology and Oral Radiology", "Endodontology" and "Turkish Journal of Medical Sciences".

\section{Search}

The PubMed and EMBASE resource databases were explored through advanced searches. An organized and logical approach was used to categorize the studies dealing with the association between PICF biomarkers and peri-implant diseases. The keywords and search inquiries used during the primary stage were as follows: "peri implant crevicular fluid" OR "peri-implant crevicular fluid" AND "peri implant sulcus fluid" AND "peri-implant sulcus fluid" AND "peri-implantitis" OR "peri implantitis" AND "peri-implant inflammation" OR "peri implant inflammation" AND "peri-implant infection" OR "peri-implant infection" AND "peri-implant mucositis" OR "peri implant mucositis" AND "implant biomarkers" AND "implant enzymes". The choice of keywords was intended to be broad to collect as much relevant data as possible without relying on electronic means alone to refine the search results. After advance search; the studies dealing with peri-implantitis or peri-implant mucositis and PICF biomarker or enzyme level analysis were included in the present review.

\section{Selection of studies}

Based on the inclusion criteria, the authors independently screened titles and abstracts derived from the literature search (Figure 1). Both reviewers compared decisions and their eligibility for this review was confirmed after discussion. Full articles were obtained for all the studies considered eligible for inclusion in this paper and further evaluated by both reviewers. If needed, a third party was consulted when consensus could not be reached.

\section{Types of publications}

The present review included only human studies published in the English language. Letters, editorials, case reports, literature reviews, animal research, $\mathrm{PhD}$ theses, and abstracts were excluded.

\section{Types of studies}

The present review included all human prospective, follow-up studies, clinical trials, cohort studies, casecontrol studies, case series studies, published between January 1, 1996 and March 1, 2016, were searched that reported on biomarkers and enzyme levels obtained by PICF and/or PISF analysis.

\section{Types of participants/population}

Individuals included in the studies should have had at least one osseointegrated screw-type dental implant that presented with clinical or radiologic signs of periimplant mucositis or peri-implantitis and subjected to PICF biomarker analysis. However, studies presented with different definitions for the peri-implant diseases included. 


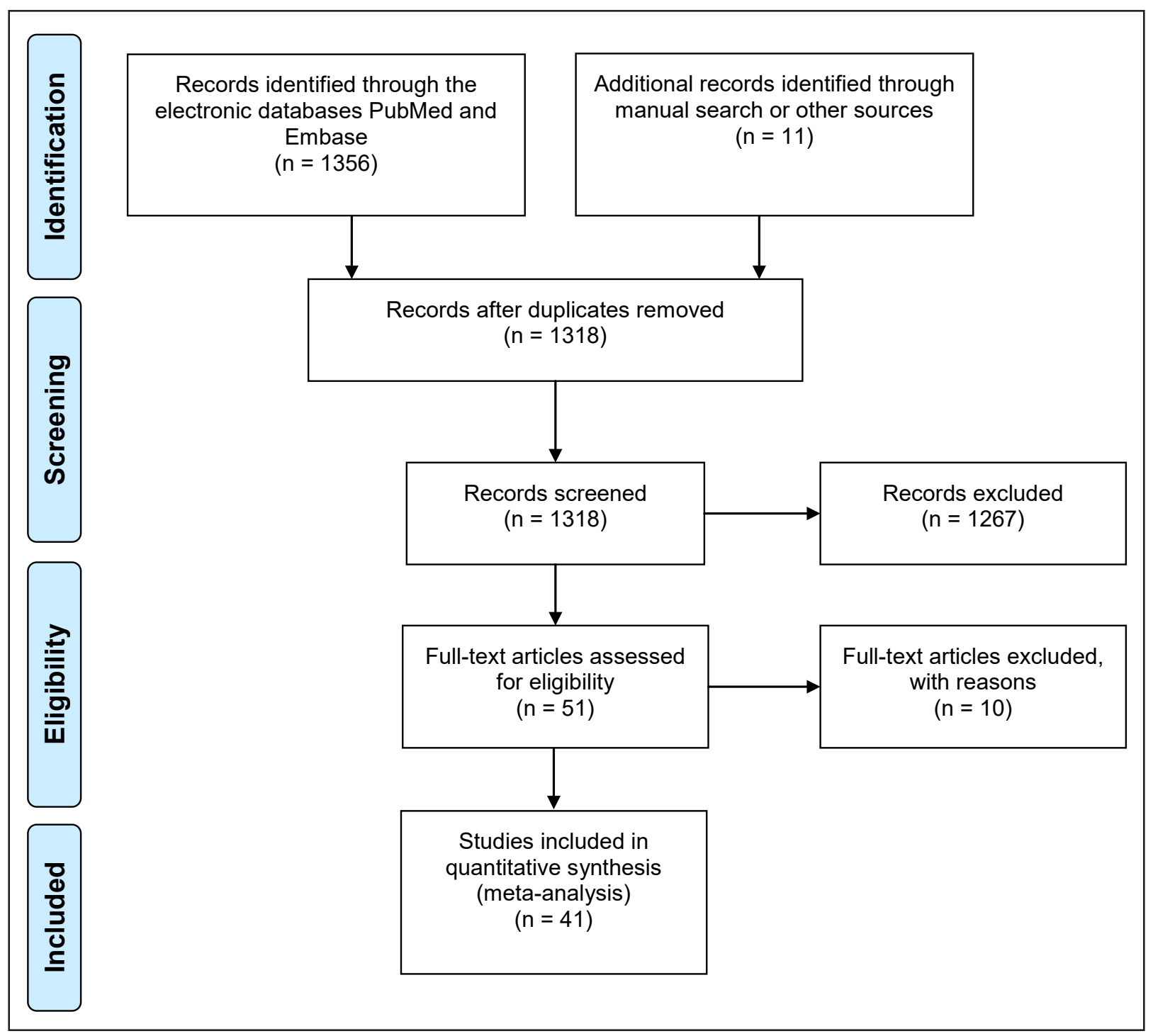

Figure 1. PRISMA flow diagram.

\section{Inclusion and exclusion criteria}

For this systematic review, original cross-sectional and longitudinal prospective clinical studies with collection of different biomarkers and enzymes in PICF from individuals with peri-implantitis (P) or peri-implant mucositis (M) were selected. Letters, editorials, case reports, literature reviews, animal research, $\mathrm{PhD}$ theses, and abstracts were excluded. Only reports in English were included. Other exclusion criteria were as follows: 1) studies with quantification of biomarkers and enzymes in tissue biopsies, serum, saliva and other biologic sources; 2) assessment of only fluid volume but not biomarker and enzyme levels; 3) fluid collection and analyses for determining the effect of different implant designs not inflammation; 4) fluid collection during early osseointegration; 5) focus on gingival distances; 6) unreported implant inflammation criteria; 7) not clear information about patient/implant groups whether healthy or periimplantitis; 8) studies assessed different biomarker genotypes.

\section{Assessment of methodological quality}

The quality of all selected trials was assessed using the recommended approach for assessing risk of bias in studies included in Cochrane reviews [9]. Evaluated parameters are: (1) random sequence generation, (2) allocation concealment, (3) blinding of participants and personnel, (4) blinding of outcome assessment, (5) incomplete outcome data, (6) selective reporting, and (7) other bias. The potential risk of bias was categorized as "low", "unclear" or "high" depending on the quality and detailed explanation of provided information about all abovementioned parameters. All assessments were completed by a single examiner (ED). 


\section{Data analyses}

Significant heterogeneity between publications in terms of diseases definitions, assessed parameters, study designs, as well as measured outcomes, among others, prevented the quantitative synthesis of the included studies and consequently a meta-analysis could not be completed. Instead, a qualitative descriptive analysis of the reported outcomes was performed and systematically reviewed in forms of tables.

\section{RESULTS}

\section{Study selection and search results}

Two reviewers based on the inclusion criteria independently screened titles derived from this comprehensive search. The reviewers compared decisions and resolved differences through discussion, consulting a third party when consensus could not be reached. The third party was an experienced senior reviewer. Full reports were obtained for all the studies judged eligible for inclusion in this paper. At the title and abstract stage, one reviewer accepted the citations that appeared to meet the inclusion criteria and sent them on for full-text review, with a second reviewer assessing only those citations the first reviewer believed ineligible.

The electronic search strategy provided 1318 titles. After title screening and abstract reading, 1267 studies were excluded because they did not fit the inclusion criteria. The participants of all studies selected were in good general health and had not received any medication (e.g. antibiotics, and/or anti-inflammatory and/or immunosuppressive agents that could affect the peri-implantitis biologic process at the time of PICF sampling.

\section{Study characteristics}

The characteristics of the 41 included articles are summarized in Table 1. The most prevalent study design was cross-sectional $(n=32)$ followed by interventional $(n=5)$. A great variability in PICF collection and biomarker or enzyme assessment was observed, and many different biomarkers and enzymes have been reported across the studies. The participants of all included studies were in general health and had not received any medication that may affect the periimplant disease process. A wide range of biomarkers and enzymes used to explore an association between studied marker and peri-implant diseases.

After full text reading, the 10 studies were excluded due to following reasons: 1) focus on the comparison of PICF interleukin-1 beta (IL-1 $\beta$ ) and plasma tumor necrosis factor-alpha (TNF- $\alpha$ ) levels between systemically healthy and diabetic subjects [10], 2) directly compare the biomarkers and enzymes of PICF around implants with gingival crevicular fluid (GCF) around natural teeth [11-15], 3) cytokine evaluation with polymerase chain reaction instead of biomarker levels [16-18], 4) sample composed of only failing implants instead of peri-implant diseases [19].

The majority of the studies used the following criteria to define the peri-implantitis: at least one peri-implant site with $\mathrm{PD}>4 \mathrm{~mm}$ with clinical signs of inflammation (BOP, suppuration and bone loss). Health implants were generally accepted as having no bone loss and no signs of inflammation. Smokers were excluded from the majority of the studies. Two studies included smokers and match the number of smokers in healthy and peri-implantitis groups $[\underline{20}, 21]$.

Most articles reported the subject numbers as well as the implants evaluated in the studies however, some of the studies reported only the number of patients and some studies reported only the number of implant sites. Of the included biomarkers and enzymes in PICF, IL-1 $\beta$ was the most studied parameter (19 studies) followed by TNF- $\alpha$ (11 studies), IL-6 (11 studies) and IL-8 (6 studies). Five studies reported oxidative stress parameters associated with periimplant inflammation and 6 studies reported matrix metallo proteinase (MMP) levels. Twenty studies compared the results between $\mathrm{P}$ and $\mathrm{H}$ sites and most studies evaluated healthy and diseased implants from different patients. Only one study performed in-patient evaluation between $\mathrm{H}$ and $\mathrm{P}$ sites [22] .

\section{Results of individual studies}

One interventional study evaluated the levels of IL-6, OPG, osteocalcin (OC), leptin, osteopontin (OPN), parathyroid hormone (PTH), TNF- $\alpha$, adiponectin and insulin levels after surgical treatment of peri-implantitis [23]. They reported no change according to the levels of OC, OPN, PTH, TNF- $\alpha$ and insulin levels and significant reduction according to total protein, MMP-8, IL6 , OPG, leptin and adiponectin levels after surgical treatment [23]. Another interventional study also reported total amount of TNF- $\alpha$ was significantly reduced at 3 and 12 months after therapy (open flap debridement) compared to baseline associated with improvements in clinical parameters [24]. Another interventional study exposed healthy implants to de novo plaque accumulation and no significant changes observed in the total amount of TNF- $\alpha$, IL$1 \beta$ and TGF- $\beta 2$ compared to baseline in PICF [25]. 
Table 1. Assessed biomarkers and enzymes in PICF for peri-implant disease

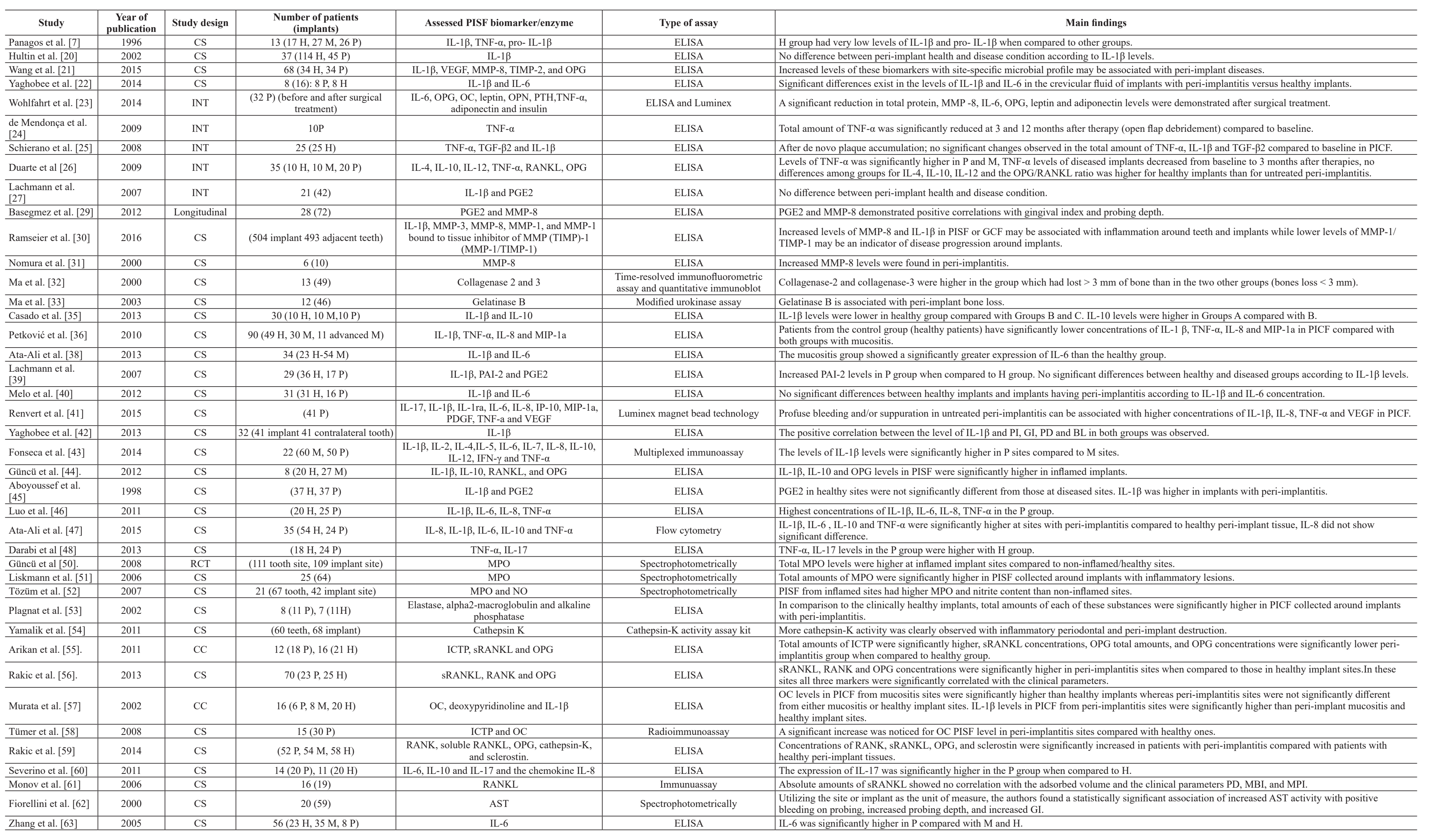

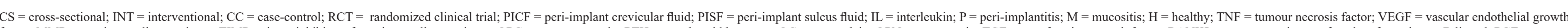

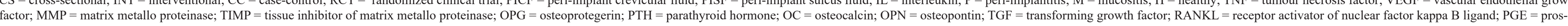

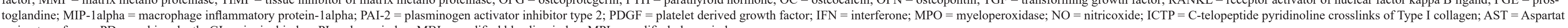
amino transferase; $\mathrm{PD}=$ probing depth; $\mathrm{GI}$ = gingival index; $\mathrm{PI}=$ plaque index; $\mathrm{MBI}$ = modified bleeding index; $\mathrm{MPI}=$ modified plaque index. 
Another study included three groups $(\mathrm{H}, \mathrm{M}, \mathrm{P})$ of implants and reported levels of TNF- $\alpha$ was significantly higher in $\mathrm{P}$ and $\mathrm{M}, \mathrm{TNF}-\alpha$ levels of diseased implants decreased from baseline to three months after therapies, no differences among groups for IL-4, IL-10, IL-12 and the osteoprotegerin (OPG) and receptor activator of $\mathrm{NFkB}$ ligand (RANKL) ratio was higher for healthy implants than for untreated peri-implantitis [26].
Another interventional study reported no difference between peri-implant health and disease condition according to IL-1 $\beta$ and PGE2 levels [27].

\section{Assessment of methodological quality}

The results of risk of bias assessment for included studies were summarized in Table 2.

Table 2. Risk of bias within the included studies

\begin{tabular}{|c|c|c|c|c|c|c|}
\hline & $\begin{array}{c}\text { Random } \\
\text { sequence } \\
\text { generation }\end{array}$ & $\begin{array}{l}\text { Allocation } \\
\text { concealment }\end{array}$ & Blinding & $\begin{array}{c}\text { Incomplete } \\
\text { outcome } \\
\text { data }\end{array}$ & $\begin{array}{l}\text { Selective } \\
\text { reporting }\end{array}$ & $\begin{array}{c}\text { Other } \\
\text { sources of } \\
\text { bias }\end{array}$ \\
\hline Panagos et al. [7] & $?$ & $?$ & - & + & + & + \\
\hline Hultin et al. [20] & $?$ & - & - & + & + & + \\
\hline Wang et al. [21] & + & + & + & + & + & + \\
\hline Yaghobee et al. [22] & $?$ & $?$ & $?$ & + & + & + \\
\hline Wohlfahrt et al. [23] & + & + & $?$ & + & + & + \\
\hline de Mendonça et al. [24] & $?$ & $?$ & $?$ & + & + & + \\
\hline Schierano et al. [25] & + & $?$ & + & + & + & + \\
\hline Duarte et al. [26] & + & + & + & + & + & + \\
\hline Lachmann et al. [27] & $?$ & + & + & $?$ & + & + \\
\hline Basegmez et al. [29] & $?$ & $?$ & $?$ & + & + & + \\
\hline Ramseier et al. [30] & + & + & $?$ & + & + & + \\
\hline Nomura et al. [31] & $?$ & $?$ & $?$ & + & + & $?$ \\
\hline Ma et al. [32] & $?$ & $?$ & $?$ & $?$ & + & + \\
\hline Ma et al. [33] & $?$ & $?$ & $?$ & + & + & + \\
\hline Casado et al. [35] & $?$ & $?$ & $?$ & + & + & + \\
\hline Petković et al. [36] & $?$ & $?$ & - & $?$ & + & $?$ \\
\hline Ata-Ali et al. [38] & $?$ & $?$ & $?$ & + & $?$ & + \\
\hline Lachmann et al. [39] & $?$ & $?$ & $?$ & + & + & + \\
\hline Melo et al. [40] & $?$ & $?$ & $?$ & + & + & + \\
\hline Renvert et al. [41] & $?$ & + & + & + & + & + \\
\hline Yaghobee et al. [42] & $?$ & $?$ & $?$ & + & + & + \\
\hline Fonseca et al. [43] & $?$ & $?$ & $?$ & + & + & + \\
\hline Güncü et al. [44]. & $?$ & $?$ & $?$ & + & + & + \\
\hline Aboyoussef et al. [45] & $?$ & $?$ & - & + & + & + \\
\hline Luo et al. [46] & $?$ & $?$ & $?$ & + & + & + \\
\hline Ata-Ali et al. [47] & $?$ & $?$ & $?$ & + & + & + \\
\hline Darabi et al. [48] & $?$ & $?$ & - & $?$ & $?$ & $?$ \\
\hline Güncü et al. [50] & + & $?$ & $?$ & + & + & + \\
\hline Liskmann et al. [51] & $?$ & $?$ & $?$ & + & + & + \\
\hline Tözüm et al. [52] & $?$ & $?$ & $?$ & + & + & + \\
\hline Plagnat et al. [53] & $?$ & $?$ & $?$ & + & + & + \\
\hline Yamalik et al. [54] & $?$ & $?$ & $?$ & + & + & + \\
\hline Arikan et al. [55] & $?$ & $?$ & $?$ & + & + & + \\
\hline Rakic et al. [56] & $?$ & $?$ & $?$ & + & + & + \\
\hline Murata et al. [57] & $?$ & $?$ & $?$ & + & + & + \\
\hline Tümer et al. [58] & $?$ & $?$ & $?$ & + & + & + \\
\hline Rakic et al. [59] & $?$ & $?$ & $?$ & + & + & + \\
\hline Severino et al. [60] & $?$ & $?$ & $?$ & + & + & + \\
\hline Monov et al. [61] & $?$ & $?$ & $?$ & + & + & + \\
\hline Fiorellini et al. [62] & $?$ & $?$ & $?$ & + & + & + \\
\hline Zhang et al. [63] & $?$ & $?$ & $?$ & + & + & + \\
\hline
\end{tabular}

$+=$ low risk; $?=$ unclear risk $;-=$ high risk 


\section{DISCUSSION}

The current evidence according to the PICF levels of biomarkers and enzymes that used to distinguish between healthy and inflamed implant sites and their diagnostic and prognostic potential for prediction of future peri-implantitis was assessed and results from 41 original were explored in the present review. It is obvious that a wide range of biomarkers and enzymes are reported to be involved in peri-implant inflammation (Table 1). The PICF levels of 13 different cytokines (IL-1 $\beta$, IL-2, IL-4, IL-5, IL-6, IL-7, IL-8, IL-10, IL-12, IL-17, IFN- $\gamma$, PGE-2 and TNF- $\alpha$ ) have been compared in different clinical peri-implant conditions. MMPs are endopeptidases capable of degrading various extracellular matrix proteins and play a role in cell proliferation, differentiation, migration, and apoptosis [28]. Periimplantitis has been shown to demonstrate a similar pattern of destruction as periodontitis, and MMP upregulation has been associated with irreversible peri-implant connective tissue destruction [28]. Six studies assessed collagenases in PICF in different peri-implantitis lesions which are important around peri-implant tissues, are MMP-1, MMP-3, MMP8, and MMP-13 and tissue inhibitors [21,29-33] And according to all included studies, MMPs were reported to be positively correlated with clinical inflammatory conditions around implants $[\underline{21}, 29-33]$. IL- $1 \beta$ and TNF- $\alpha$ are the two most targeted biomarkers among the majority of included studies and take part in osteoclast formation and bone resorption $[6,34-36]$. IL-1 $\beta$ regulates the degradation of extracellular matrix components of the plasminogen system and the collagenase activity in inflammation and wound healing $[\underline{35}, 37]$. It has been shown that inhibition of IL- $1 \beta$ reduced tissue breakdown and the progression of tissue inflammation [26]. TNF- $\alpha$ induces fibroblast apoptosis and reduction of the repair capacity of the peri-implant tissue, but mechanical therapy seems to revert this situation [26]. Of the 19 studies assessed IL-1 $\beta, 5$ of them showed no statistically significant differences between healthy and diseased groups $[\underline{20}, \underline{27}, \underline{38-}$ 40]. One of them reported no significant change after de novo plaque accumulation [25]. Thirteen studies showed higher levels of IL-1 $\beta$ in PICF than healthy implant sites $[\underline{7}, \underline{21}, \underline{22}, \underline{30}, \underline{35}, \underline{36}, \underline{41-}$ 47]. Of the 10 studies assessed TNF- $\alpha, 3$ of them showed no relationship with this cytokine with peri-implant inflammation $[\underline{7}, \underline{25}, \underline{43}]$, while other 7 studies showed significant relationship with this cytokine $[\underline{23}, \underline{24}, \underline{36}, \underline{41}, \underline{46-48}]$. These findings suggest that pro-inflammatory cytokines such as IL-1 $\beta$ and TNF- $\alpha$ are up to date, the most promising proteins to be used as markers in PICF for differentiation between peri-implantitis and healthy implants.

Although ILs are the most of interest in PICF analyses followed by MMPs, there are other biomarkers and enzymes that their levels were evaluated to reflect the local inflammatory condition of implants. Myeloperoxidase (MPO) is an antimicrobial leukocyte-derived enzyme found in high concentrations in the primary granules of leukocytes that catalyzes the formation of a number of reactive oxidant species [48]. Three studies reported significantly higher amounts of MPO in PISF collected around implants with inflammatory lesions [50-52]. In the peri-implant region as well as the natural dentition, it has also been demonstrated that no metabolism is closely related to the status and degree of peri-implant inflammation [52]

Elastase is a major enzyme released from human leukocytes and contributes to tissue damage during inflammation, significantly higher amounts of alkaline phosphatase and elastase were found in PISF around implants with peri-implantitis compared with healthy controls [53]. Prostaglandin $\mathrm{E}_{2}\left(\mathrm{PGE}_{2}\right)$ is a vasodilator that increases vascular permeability at sites of inflammation and also has a role in bone resorption. One study reported that $\mathrm{PGE}_{2}$ showed positive correlations with gingival index and $\mathrm{PD}$ [29], 2 studies reported no difference between peri-implant health and disease condition according to PICF levels $[27,45]$. Another enzyme associated with bone resorption is cathepsin- $\mathrm{K}$, which is a protease that is released during the inflammatory process after tissue injury. Yamalik et al. [54] showed that cathepsin-K activity was positively correlated with the volume of PISF where there was also inflammatory bone loss, indicating it could be a biomarker used to predict or assess peri-implant alveolar bone loss. Additional biomarkers for peri-implant bone loss have also been studied for peri-implant diseases. OPG/RANKL are both produced by osteoblasts. RANKL normally binds to RANK, which is originate on the surfaces of osteoclast precursors as well as mature osteoclasts, and this binding is necessary for their formation, function, and existence. OPG acts as a trap receptor for RANKL, and its binding prevents RANKL binding to RANK, thereby inhibiting the differentiation of an osteoclast precursor into a mature osteoclast. Arikan et al. [55] reported that sRANKL concentrations, OPG total amounts, and OPG concentrations were significantly lower in peri-implantitis group when compared to healthy group. In contrast, RANKL, RANK, and OPG concentrations were found 
to be significantly higher in peri-implantitis sites compared with healthy implant sites, but the ratio of OPG/RANKL was not different [56]. It was also demonstrated that the OPG/RANKL ratio improved with mechanical treatment of peri-implantitis sites [26]. Osteocalcin is a $5.4-\mathrm{kDa}$ calcium-binding protein of bone and the most abundant non-collagenous protein of the mineralized bone tissue [57]. One study reported higher osteocalcin (OC) levels in PICF as possible biomarker to define the inflammatory conditions around implants [58] whereas two studies reported conflicting results for PICF OC levels $[\underline{23}, \underline{57}]$.

\section{Limitations}

First limitation of the present systematic review is the wide range of different definitions regarding periimplant mucositis and peri-implantitis that were employed in the included investigations. Another limitation is a lack of information on whether the inflammatory markers in PICF were matched for the clinical parameters of the respective collection sites, such as PD, clinical attachment loss, and BOP. This is a vital point due to a strong link between PICF biomarker levels and severity and extent of local inflammatory disease. The majority of studies reported the mean clinical parameters of all implant sites or did not clarify whether the clinical parameters presented were related to all implant sites or to sites selected for PICF sampling. Another limitation is; much evidence came from cross-sectional studies. Due to a cyclic progression of peri-implant diseases, the immune-inflammatory event biomarkers responsible for tissue breakdown may not always be active in cross-sectional studies with a single moment of fluid collection.

\section{CONCLUSIONS}

For better understanding of the immune inflammatory peri-implant diseases and for developing hostmodulation therapies, biomarkers plays a crucial role to aid clinicians to elucidate the complex biologic process involved. Based on this systematic review, it was concluded that inflammatory mediators, such as interleukin-1 beta and plasma tumor necrosis factoralpha, in crevicular fluid collected from peri-implant pockets are the most used biomarkers to assist in the early diagnosis of peri-implantitis. It is suggested that studies should be conducted to establish a standardized method to diagnose and classify the peri-implant diseases. Standardized investigations should be performed based on the criteria of subject selection, peri-implantitis diagnosis, as well as periimplant crevicular fluid sampling method (e.g. number and severity of sampling sites, sampling time), sample handling and detection sensitivity/specificity of the used assay.

\section{ACKNOWLEDGMENTS AND DISCLOSURE STATEMENTS}

The authors report no conflicts of interest related to this study.

\section{REFERENCES}

1. Peri-implant mucositis and peri-implantitis: a current understanding of their diagnoses and clinical implications. J Periodontol. 2013 Apr;84(4):436-43. [Medline: 23537178] [doi: 10.1902/jop.2013.134001]

2. Smeets R, Henningsen A, Jung O, Heiland M, Hammächer C, Stein JM. Definition, etiology, prevention and treatment of peri-implantitis--a review. Head Face Med. 2014 Sep 3;10:34. [Medline: 25185675] [PMC free article: 4164121] [doi: 10.1186/1746-160X-10-34]

3. Mombelli A, Muller N, Cionca N. The epidemiology of peri-implantitis. Clin Oral Implants Res 2012; 23 Suppl 6:67-76. [Medline: 23062130] [doi: 10.1111/j.1600-0501.2012.02541.x]

4. Derks J, Tomasi C. Peri-implant health and disease. A systematic review of current epidemiology. Clin Oral Implants Res. 2012 Oct;23 Suppl 6:67-76. [Medline: 25495683] [doi: 10.1111/jcpe.12334]

5. Heitz-Mayfield LJ. Peri-implant diseases: diagnosis and risk indicators. J Clin Periodontol. 2008 Sep;35(8 Suppl):292-304. [Medline: 18724857] [doi: 10.1111/j.1600-051X.2008.01275.x]

6. Li JY, Wang HL. Biomarkers associated with periimplant diseases. Implant Dent. 2014 Oct;23(5):607-11. [Medline: 25192154] [doi: 10.1097/id.0000000000000129]

7. Panagakos FS, Aboyoussef H, Dondero R, Jandinski JJ. Detection and measurement of inflammatory cytokines in implant crevicular fluid: a pilot study. Int J Oral Maxillofac Implants. 1996 Nov-Dec;11(6):794-9. [Medline: 8990643]

8. Moher D, Liberati A, Tetzlaff J, Altman DG; PRISMA Group. Preferred reporting items for systematic reviews and metaanalyses: the PRISMA statement. Int J Surg. 2010;8(5):336-41. [Medline: 20171303] [doi: 10.1016/j.ijsu.2010.02.007] 
9. Higgins J, Altman DG, Sterne J. Chapter 8: Assessing risk of bias in included studies. Cochrane Handbook for Systematic Reviews of Interventions Version 5.1.0 [updated March 2011]. Cochrane Handbook for Systematic Reviews 2011. [URL: http://training.cochrane.org/handbook]

10. Dogan SB, Kurtis MB, Tuter G, Serdar M, Watanabe K, Karakis S. Evaluation of Clinical Parameters and Levels of Proinflammatory Cytokines in the Crevicular Fluid Around Dental Implants in Patients with Type 2 Diabetes Mellitus. Int J Oral Maxillofac Implants. 2015 Sep-Oct;30(5):1119-27. [Medline: 26394349] [doi: 10.11607/jomi.3787]

11. Machtei EE, Oved-Peleg E, Peled M. Comparison of clinical, radiographic and immunological parameters of teeth and different dental implant platforms. Clin Oral Implants Res. 2006 Dec;17(6):658-65. [Medline: 17092224] [doi: $10.1111 / \mathrm{j} .1600-0501.2006 .01282 . x$ ]

12. Nowzari H, Botero JE, DeGiacomo M, Villacres MC, Rich SK. Microbiology and cytokine levels around healthy dental implants and teeth. Clin Implant Dent Relat Res. 2008 Sep;10(3):166-73. [doi: 10.1111/j.1708-8208.2007.00076.x] [Medline: 18218050]

13. Recker EN, Avila-Ortiz G, Fischer CL, Pagan-Rivera K, Brogden KA, Dawson DV, Elangovan S. A cross-sectional assessment of biomarker levels around implants versus natural teeth in periodontal maintenance patients. J Periodontol. 2015 Feb;86(2):264-72. [Medline: 25269523] [PMC free article: 4394381] [doi: 10.1902/jop.2014.140354]

14. Vieira AE, Moura CC, de Souza MA, Zanetta-Barbosa D, Dechichi P. Would nitric oxide be an effective marker for earlier stages of peri-implant disease? An analysis in human peri-implant sulcular fluid. J Oral Implantol. 2013 Feb;39(1):37-43. [Medline: 23402357] [doi: 10.1563/AAID-JOI-D-11-00158]

15. Nowzari H, Phamduong S, Botero JE, Villacres MC, Rich SK. The profile of inflammatory cytokines in gingival crevicular fluid around healthy osseointegrated implants. Clin Implant Dent Relat Res. 2012 Aug;14(4):546-52. [Medline: 20662860] [doi: $10.1111 / \mathrm{j} .1708-8208.2010 .00299 . x]$

16. Cosgarea R, Dannewitz B, Sculean A, Bran S, Rotaru H, Baciut G, Eick S. Bacterial and inflammatory behavior of implants in the early healing phase of chronic periodontitis. Quintessence Int. 2012 Jun;43(6):491-501. [Medline: 22532956]

17. Hall J, Britse AO, Jemt T, Friberg B. A controlled clinical exploratory study on genetic markers for peri-implantitis. Eur J Oral Implantol. 2011 Winter;4(4):371-82. [Medline: 22282733]

18. Hall J, Pehrson NG, Ekestubbe A, Jemt T, Friberg B. A controlled, cross-sectional exploratory study on markers for the plasminogen system and inflammation in crevicular fluid samples from healthy, mucositis and peri-implantitis sites. Eur J Oral Implantol. 2015 Summer;8(2):153-66. [Medline: 26021226]

19. Salcetti JM, Moriarty JD, Cooper LF, Smith FW, Collins JG, Socransky SS, Offenbacher S. The clinical, microbial, and host response characteristics of the failing implant. Int J Oral Maxillofac Implants. 1997 Jan-Feb;12(1):32-42. [Medline: 9048452]

20. Hultin M, Gustafsson A, Hallstrom H, Johansson LA, Ekfeldt A, Klinge B. Microbiological findings and host response in patients with peri-implantitis. Clin Oral Implants Res. 2002 Aug;13(4):349-58. [Medline: 12175371] [doi: 10.1034/i.1600-0501.2002.130402.x]

21. Wang HL, Garaicoa-Pazmino C, Collins A, Ong HS, Chudri R, Giannobile WV. Protein biomarkers and microbial profiles in peri-implantitis. Clin Oral Implants Res. 2015 Oct 1. [Medline: 26424287] [doi: 10.1111/clr.12708]

22. Yaghobee S, Khorsand A, Rasouli Ghohroudi AA, Sanjari K, Kadkhodazadeh M. Assessment of interleukin1 beta and interleukin- 6 in the crevicular fluid around healthy implants, implants with peri-implantitis, and healthy teeth: a cross-sectional study. J Korean Assoc Oral Maxillofac Surg. 2014 Oct;40(5):220-4. [Medline: 25368834] [PMC free article: $\underline{4217267]}$ [doi: $10.5125 / \mathrm{jkaoms} .2014 .40 .5 .220]$

23. Wohlfahrt JC, Aass AM, Granfeldt F, Lyngstadaas SP, Reseland JE. Sulcus fluid bone marker levels and the outcome of surgical treatment of peri-implantitis. J Clin Periodontol. 2014 Apr;41(4):424-31. [Medline: 24417563] [doi: $10.1111 /$ jepe.12229]

24. de Mendonça AC, Santos VR, César-Neto JB, Duarte PM. Tumor necrosis factor-alpha levels after surgical anti-infective mechanical therapy for peri-implantitis: a 12-month follow-up. J Periodontol. 2009 Apr;80(4):693-9. [Medline: 19335091] [doi: 10.1902/jop.2009.080521]

25. Schierano G, Pejrone G, Brusco P, Trombetta A, Martinasso G, Preti G, Canuto RA. TNF-alpha TGF-beta2 and IL-1beta levels in gingival and peri-implant crevicular fluid before and after de novo plaque accumulation. J Clin Periodontol. 2008 Jun;35(6):532-8. [Medline: 18384390] [doi: 10.1111/j.1600-051X.2008.01224.x]

26. Duarte PM, de Mendonça AC, Máximo MB, Santos VR, Bastos MF, Nociti FH. Effect of anti-infective mechanical therapy on clinical parameters and cytokine levels in human peri-implant diseases. J Periodontol. 2009 Feb;80(2):234-43. [Medline: 19186963] [doi: 10.1902/jop.2009.070672]

27. Lachmann S, Kimmerle-Müller E, Axmann D, Gomez-Roman G, Weber H, Haas R. Reliability of findings around healthy implants in association with oral hygiene measures: a clinical, microbiological, and immunological follow-up in edentulous patients. Clin Oral Implants Res. 2007 Dec;18(6):686-98.[Medline: 17991251] [doi: 10.1111/j.1600-0501.2007.01399.x]

28. Klinge B, Gustafsson A, Berglundh T. A systematic review of the effect of anti-infective therapy in the treatment of periimplantitis. J Clin Periodontol. 2002;29 Suppl 3:213-25; discussion 232-3. Review. [Medline: 12787221]

29. Basegmez C, Yalcin S, Yalcin F, Ersanli S, Mijiritsky E. Evaluation of periimplant crevicular fluid prostaglandin E2 and matrix metalloproteinase-8 levels from health to periimplant disease status: a prospective study. Implant Dent. 2012 Aug;21(4):306-10. [Medline: 22814555] [doi: 10.1097/ID.0b013e3182588408] 
30. Ramseier CA, Eick S, Brönnimann C, Buser D, Brägger U, Salvi GE. Host-derived biomarkers at teeth and implants in partially edentulous patients. A 10-year retrospective study. Clin Oral Implants Res. 2016 Feb;27(2):211-7. [Medline: 25682848] [doi: 10.1111/clr.12566]

31. Nomura T, Ishii A, Shimizu H, Taguchi N, Yoshie H, Kusakari H, Hara K. Tissue inhibitor of metalloproteinases-1, matrix metalloproteinases-1 and -8 , and collagenase activity levels in peri-implant crevicular fluid after implantation. Clin Oral Implants Res. 2000 Oct;11(5):430-40. [Medline: 11168235] [doi: 10.1034/j.1600-0501.2000.011005430.x]

32. Ma J, Kitti U, Teronen O, Sorsa T, Husa V, Laine P, Rönkä H, Salo T, Lindqvist C, Konttinen YT. Collagenases in different categories of peri-implant vertical bone loss. J Dent Res. 2000 Nov;79(11):1870-3. [Medline: 11145357] [doi: $10.1177 / 00220345000790110901$ ]

33. Ma J, Kitti U, Hanemaaijer R, Teronen OP, Sorsa TA, Natah S, Tensing EK, Konttinen YT. Gelatinase B is associated with peri-implant bone loss. Clin Oral Implants Res. 2003 Dec;14(6):709-13. [Medline: 15015946] [doi: 10.1046/j.09057161.2003.00951.x]

34. Ataoglu H, Alptekin NO, Haliloglu S, Gursel M, Ataoglu T, Serpek B, Durmus E. Interleukin-1beta, tumor necrosis factoralpha levels and neutrophil elastase activity in peri-implant crevicular fluid. Clin Oral Implants Res. 2002 Oct;13(5): 470-6. [Medline: 12453123] [doi: 10.1034/j.1600-0501.2002.130505.x]

35. Casado PL, Canullo L, de Almeida Filardy A, Granjeiro JM, Barboza EP, Leite Duarte ME. Interleukins $1 \beta$ and 10 expressions in the periimplant crevicular fluid from patients with untreated periimplant disease. Implant Dent. 2013 Apr;22(2):143-50. [Medline: 23459153] [doi: 10.1097/ID.0b013e3182818792]

36. Petković AB, Matić SM, Stamatović NV, Vojvodić DV, Todorović TM, Lazić ZR, Kozomara RJ. Proinflammatory cytokines (IL-1beta and TNF-alpha) and chemokines (IL-8 and MIP-1alpha) as markers of peri-implant tissue condition. Int J Oral Maxillofac Surg. 2010 May;39(5):478-85. [Medline: 20207110] [doi: 10.1016/j.ijom.2010.01.014]

37. Kao RT, Curtis DA, Richards DW, Preble J. Increased interleukin-1 beta in the crevicular fluid of diseased implants. Int J Oral Maxillofac Implants. 1995 Nov-Dec;10(6):696-701. [Medline: 8530172]

38. Ata-Ali J, Flichy-Fernandez AJ, Ata-Ali F, Penarrocha-Diago M, Penarrocha-Diago M. Clinical, microbiologic, and host response characteristics in patients with peri-implant mucositis. Int J Oral Maxillofac Implants. 2013 MayJun;28(3):883-90. [Medline: 23748323] [doi: 10.11607/jomi.2654]

39. Lachmann S, Kimmerle-Müller E, Axmann D, Scheideler L, Weber H, Haas R. Associations between peri-implant crevicular fluid volume, concentrations of crevicular inflammatory mediators, and composite IL-1A -889 and IL-1B +3954 genotype. A cross-sectional study on implant recall patients with and without clinical signs of peri-implantitis. Clin Oral Implants Res. 2007 Apr;18(2):212-23. [Medline: 17348886] [doi: 10.1111/j.1600-0501.2006.01322.x]

40. Melo RF, Lopes BM, Shibli JA, Marcantonio E Jr, Marcantonio RA, Galli GM. Interleukin-1 $\beta$ and interleukin-6 expression and gene polymorphisms in subjects with peri-implant disease. Clin Implant Dent Relat Res. 2012 Dec;14(6):905-14. [Medline: 21414132] [doi: 10.1111/j.1708-8208.2010.00325.x]

41. Renvert S, Widén C, Persson GR. Cytokine expression in peri-implant crevicular fluid in relation to bacterial presence. J Clin Periodontol. 2015 Jul;42(7):697-702. [Medline: 26085219] [doi: 10.1111/jcpe.12422]

42. Yaghobee S, Khorsand A, Paknejad M. Comparison of interleukin-1 $\beta$ levels in gingival crevicular fluid and peri-implant crevicular fluid and its relationship with clinical indexes. J Dent (Tehran). 2013 Jan;10(1):1-9. [Medline: 23724197] [PMC free article: 3666058$]$

43. Fonseca FJ, Moraes Junior M, Lourenço EJ, Teles Dde M, Figueredo CM. Cytokines expression in saliva and periimplant crevicular fluid of patients with peri-implant disease. Clin Oral Implants Res. 2014 Feb;25(2):e68-72. [Medline: 23106689] [doi: 10.1111/clr.12052]

44. Güncü GN, Akman AC, Günday S, Yamalık N, Berker E. Effect of inflammation on cytokine levels and bone remodelling markers in peri-implant sulcus fluid: a preliminary report. Cytokine. 2012 Aug;59(2):313-6. [Medline: 22592038] [doi: 10.1016/j.cyto.2012.04.024]

45. Aboyoussef H, Carter C, Jandinski JJ, Panagakos FS. Detection of prostaglandin E2 and matrix metalloproteinases in implant crevicular fluid. Int J Oral Maxillofac Implants. 1998 Sep-Oct;13(5):689-96. [Medline: 9796154]

46. Luo L, Xie P, Gong P, Tang XH, Ding Y, Deng LX. Expression of HMGB1 and HMGN2 in gingival tissues, GCF and PICF of periodontitis patients and peri-implantitis. Arch Oral Biol. 2011 Oct;56(10):1106-11. [Medline: 21570059] [doi: 10.1016/j.archoralbio.2011.03.020]

47. Ata-Ali J, Flichy-Fernández AJ, Alegre-Domingo T, Ata-Ali F, Palacio J, Peñarrocha-Diago M. Clinical, microbiological, and immunological aspects of healthy versus peri-implantitis tissue in full arch reconstruction patients: a prospective cross-sectional study. BMC Oral Health. 2015 Apr 1;15:43. [Medline: 25888355] [PMC free article: 4391105] [doi: 10.1186/s12903-015-0031-9]

48. Darabi E, Kadkhoda Z, Amirzargar A. Comparison of the levels of tumor necrosis factor- $\alpha$ and interleukin-17 in gingival crevicular fluid of patients with peri-implantitis and a control group with healthy implants. Iran J Allergy Asthma Immunol. 2013 Mar;12(1):75-80. [Medline: 23454782]

49. Cao CF, Smith QT. Crevicular fluid myeloperoxidase at healthy, gingivitis and periodontitis sites. J Clin Periodontol. 1989 Jan;16(1):17-20. [Medline: 2536761] [doi: 10.1111/j.1600-051X.1989.tb01606.x] 
50. Güncü GN, Tözüm TF, Güncü MB, Yamalik N, Tümer C, Karabulut E, Kilinç K. Myeloperoxidase as a measure of polymorphonuclear leukocyte response in inflammatory status around immediately and delayed loaded dental implants: a randomized controlled clinical trial. Clin Implant Dent Relat Res. 2008 Mar;10(1):30-9. [Medline: 18335584] [doi: $10.1111 / \mathrm{j} .1708-8208.2007 .00058 . \mathrm{x}]$

51. Liskmann S, Vihalemm T, Salum O, Zilmer K, Fischer K, Zilmer M. Correlations between clinical parameters and interleukin-6 and interleukin-10 levels in saliva from totally edentulous patients with peri-implant disease. Int J Oral Maxillofac Implants. 2006 Jul-Aug;21(4):543-50. [Medline: 16955604]

52. Tözüm TF, Akman AC, Yamalik N, Tulunoglu I, Turkyilmaz I, Karabulut E, Kilinc K, Cehreli MC. Analysis of the inflammatory process around endosseous dental implants and natural teeth: myeloperoxidase level and nitric oxide metabolism. Int J Oral Maxillofac Implants. 2007 Nov-Dec;22(6):969-79. [Medline: 18271379]

53. Plagnat D, Giannopoulou C, Carrel A, Bernard JP, Mombelli A, Belser UC. Elastase, alpha2-macroglobulin and alkaline phosphatase in crevicular fluid from implants with and without periimplantitis. Clin Oral Implants Res. 2002 Jun;13(3):227-33. [Medline: 12010152] [doi: 10.1034/j.1600-0501.2002.130301.x]

54. Yamalik N, Günday S, Kilinc K, Karabulut E, Berker E, Tözüm TF. Analysis of cathepsin-K levels in biologic fluids from healthy or diseased natural teeth and dental implants. Int J Oral Maxillofac Implants. 2011 Sep-Oct;26(5):991-7. [Medline: 22010081]

55. Arikan F, Buduneli N, Lappin DF. C-telopeptide pyridinoline crosslinks of type I collagen, soluble RANKL, and osteoprotegerin levels in crevicular fluid of dental implants with peri-implantitis: a case-control study. Int J Oral Maxillofac Implants. 2011 Mar-Apr;26(2):282-9. [Medline: 21483881]

56. Rakic M, Lekovic V, Nikolic-Jakoba N, Vojvodic D, Petkovic-Curcin A, Sanz M. Bone loss biomarkers associated with peri-implantitis. A cross-sectional study. Clin Oral Implants Res. 2013 Oct;24(10):1110-6. [Medline: 22708989] [doi: 10.1111/j.1600-0501.2012.02518.x]

57. Murata M, Tatsumi J, Kato Y, Suda S, Nunokawa Y, Kobayashi Y, Takeda H, Araki H, Shin K, Okuda K, Miyata T, Yoshie H. Osteocalcin, deoxypyridinoline and interleukin-1beta in peri-implant crevicular fluid of patients with peri-implantitis. Clin Oral Implants Res. 2002 Dec;13(6):637-43. [Medline: 12519339] [doi: 10.1034/j.1600-0501.2002.130610.x]

58. Tümer C, Aksoy Y, Güncü GN, Nohutcu RM, Kilinc K, Tözüm TF. Possible impact of inflammatory status on C-telopeptide pyridinoline cross-links of type I collagen and osteocalcin levels around oral implants with peri-implantitis: a controlled clinical trial. J Oral Rehabil. 2008 Dec;35(12):934-9. [Medline: 19090910] [doi: 10.1111/j.1365-2842.2008.01879.x]

59. Rakic M, Struillou X, Petkovic-Curcin A, Matic S, Canullo L, Sanz M, Vojvodic D. Estimation of bone loss biomarkers as a diagnostic tool for peri-implantitis. J Periodontol. 2014 Nov;85(11):1566-74. [Medline: 24878328] [doi: 10.1902/jop.2014.140069]

60. Severino VO, Napimoga MH, de Lima Pereira SA. Expression of IL-6, IL-10, IL-17 and IL-8 in the peri-implant crevicular fluid of patients with peri-implantitis. Arch Oral Biol. 2011 Aug;56(8):823-8. [Medline: 21306703] [doi: 10.1016/j.archoralbio.2011.01.006]

61. Monov G, Strbac GD, Baron M, Kandler B, Watzek G, Gruber R. Soluble RANKL in crevicular fluid of dental implants: a pilot study. Clin Implant Dent Relat Res. 2006;8(3):135-41. [Medline: 16919021] [doi: 10.1111/j.1708-8208.2006.00012.x]

62. Fiorellini JP, Nevins ML, Sekler J, Chung A, Oringer RJ. Correlation of peri-implant health and aspartate aminotransferase levels: a cross-sectional clinical study. Int J Oral Maxillofac Implants. 2000 Jul-Aug;15(4):500-4. [Medline: 10960982]

63. Zhang Y, Wang C, Jinbu Y, Itoh H, Kusama M. Increased IL-6 levels in peri-implant crevicular fluid correlate with periimplantitis. Oral Med Pathol 2005 Apr;10(3):95-9. [doi: 10.3353/omp.10.95]

\section{To cite this article:}

Dursun E, Tözüm TF.

Peri-Implant Crevicular Fluid Analysis, Enzymes and Biomarkers: a Systemetic Review

J Oral Maxillofac Res 2016;7(3):e9

URL: http://www.ejomr.org/JOMR/archives/2016/3/e9/v7n3e9.pdf

doi: $10.5037 /$ jomr.2016.7309

Copyright (C) Dursun E, Tözüm TF. Published in the JOURNAL OF ORAL \& MAXILLOFACIAL RESEARCH (http://www.ejomr.org), 9 September 2016.

This is an open-access article, first published in the JOURNAL OF ORAL \& MAXILLOFACIAL RESEARCH, distributed under the terms of the Creative Commons Attribution-Noncommercial-No Derivative Works 3.0 Unported License, which permits unrestricted non-commercial use, distribution, and reproduction in any medium, provided the original work and is properly cited. The copyright, license information and link to the original publication on (http://www.ejomr.org) must be included. 